\title{
EKSTRAKSI HIDROKARBON DARI BEBERAPA MIKROALGA
}

\author{
(Extraction of Hydrocarbon from Several Microalgae)
}

\author{
Hendri Bawole $^{1^{\star}}$, Rizald M. Rompas ${ }^{2}$, Elvy L. Ginting ${ }^{1}$ \\ 1. Program Studi IImu Kelautan, Fakultas Perikanan dan IImu Kelautan, Universitas Sam \\ Ratulangi, Manado \\ 2. Koordinator PS-Doktor IImu Kelautan \\ *e-mail:hbawole14@gmail.com
}

The research objectives were to extract, determine the oil weight contained in microalgae Nannochloropsis sp. Chlorella sp. and Spirulina sp., and to see how the cell wall algae was breakdown through either heating or sonicating. Nannochloropsis sp., were obtained from Balai Besar Budidaya Laut Lampung, and Chlorella sp. and Spirulina sp. were taken from Balai Besar Budidaya Laut and Payau Jepara. The cell wall of each sample was demolished by heating and sonycator process. These samples were then macerated in $n$-hexane for 24 hours. Furthermore, $n$-hexane solution was moved into the clear glass bottle to evaporate. The apparent oil spot in the bottle indicated that the extraction processes was successful. The study showed that the use of sonicator was better than heating. In addition, Spirulina sp., held the highest oil content.

Keywords: microalgae, oil extraction, cell wall demolish, sonycator

Riset ini bertujuan mengekstraksi dan menentukan berat minyak yang terkandung dalam mikroalga Nannochloropsis sp., Chlorella sp., dan Spirulina sp., serta menelisik teknik pemecahan dinding sel mikroalga dengan cara pemanasan dibandingkan pada penggunakan sonikator. Sampel Nannochloropsis sp., yang digunakan diperoleh dari Balai Besar Budaya Laut Lampung, sedang Chlorella sp., dan Spirulina sp., didapat dari Balai Besar Budidaya Laut dan Payau Jepara. Dinding sel dari masing-masing sampel dipecah dengan menggunakan panas dan sonikator. Sampel dimaserasi menggunakan pelarut $n$-hexane selama 24 jam. Minyak yang berhasil diperoleh terlihat pada bercak minyak di dinding botol. Minyak kemudian ditimbang dan dibandingkan beratnya dari setiap sampel dan setiap perlakuan. Hasil riset menunjukan sonikator menghasilkan minyak yang lebih banyak dibandingkan dengan yang diberi perlakuan panas, dimana pada sampel Nannochloropsis sp., Chlorella sp., dan Spirulina sp., rata-rata minyak tertinggi didapat dari perlakuan sonikator. Ketiga sampel uji ini ternyata jenis Spirulina sp., kandungan minyak lebih banyak.

Kata Kunci: Mikroalga, Ekstraksi Minyak, Pemecahan Dinding Sel, Sonikator

\section{PENDAHULUAN}

Saat ini dunia mengalami dilema karena kelangkaan yang disertai tingginya harga bahan bakar minyak secara global serta semakin menipisnya cadangan minyak bumi yang merupakan produk yang tidak dapat diperbaharui. Oleh karena itu, para pengambil kebijakan serta para kaum cendekia berpendapat bahwa untuk mengatasi krisis energi itu dapat memanfaatkan sumber alam hayati untuk memenuhi permintaan bahan bakar (Rompas, dkk. 2015).

Mikroalga merupakan salah satu sumberdaya alam hayati perairan yang tergolong organisme berkloroplas yang dapat menghasilkan oksigen melalui proses fotosintesis. Secara ekologi mikroalga berfungsi sebagai 
sumber makanan dan produsen primer dilautan. Mikroalga juga dikenal sebagai salah satu bahan yang dapat dimanfaatkan untuk dijadikan sebagai bahan baku penghasil energi terbarukan (Doyle dan Bell, 2011).

Penelitian ini bertujuan untuk mengekstraksi minyak yang terkandung dalam mikroalga Nannochloropsis sp., Cholorella sp., dan Spirulina sp. serta menentukan berat minyak yang dihasilkan disetiap jenis mikroalga, serta menelisik teknik pemecahan dinding sel dengan menggunakan sonikator dan teknik pemanasan.

\section{METODE PENELITIAN}

Sampel mikroalga laut yang digunakan dalam penelitian ini adalah mikroalga jenis Nannochloropsis sp. (segar/beku) yang diperoleh dari Balai Besar Budaya Laut Lampung, sedang Mikroalga Chlorella sp. dan Spirulina sp. (kering) yang diperoleh dari Balai Besar Budidaya Laut dan Payau Jepara. Sampel mikroalga kemudian disimpan dan dilakukan penelitian selanjutnya di Laboratorium Biologi Molekuler dan Farmasitika Laut, Fakultas Perikanan dan IImu Kelautan serta Laboratorium Farmasi, Fakultas Matematika dan IImu Pengetahuan Alam, Universitas Sam Ratulangi, Manado.

Prosedur penelitian dimulai dari pengambilan biomassa mikroalga laut jenis Nannochloropsis sp. Mikroalga yang beku dicairkan kemudian media airnya diukur pHnya. Sampel disentrifus dengan kecepatan 7.500 RPM dengan suhu $8^{\circ} \mathrm{C}$ selama 30 menit. Debris yang telah terkumpul dalam botol dicuci dengan aquades lalu disentrifus kembali pada 7.500 RPM dengan suhu $8^{\circ} \mathrm{C}$ selama 15 menit. Tahap pencucian dilakukan sebanyak tiga kali. Setelah itu dikeringkan pada suhu ruangan. Untuk sampel mikroalga Chlorella sp., dan Spirulina sp. tidak dicairkan sebagaimana pada jenis Nannochloropsis sp., karena sudah dalam keadaan kering.
Sampel mikroalga yang sudah dalam keadaan kering kemudian masuk dalam proses penghancuran dinding sel. Masing-masing jenis mikroalga kering ditimbang sebanyak $2 \mathrm{gr}$ dan dimasukkan ke dalam botol sampel. Sampel yang diberi perlakuan panas dimasukkan ke dalam panci yang telah berisi air, kemudian dipanaskan hingga mendidih. Setelah mendidih angkat dan dinginkan. Sampel yang diberi pelakuan sonikator, disonikasi selama 20 menit, sedang sebagai kontrol tidak diberi perlakuan apa-apa.

Lebih lanjut dilakukan proses
ekstraksi minyak dengan cara menambahkan $n$-hexane sebanyak 10 $\mathrm{ml}$ pada setiap botol kemudian dimaserasi (didiamkan) selama 24 jam. Setelah 24 jam, larutan n-hexane dari setiap botol sampel kaca gelap dipindahkan ke dalam botol kaca bening untuk diuapkan. Selanjutnya amati apakah ada tidaknya pembentukan minyak yang ditandai dengan adanya bercak minyak pada dinding botol. Minyak yang diperoleh kemudian ditimbang untuk membandingkan berat minyak dari masing-masing perlakuan dan kontrol. Setelah itu dilakukan analisis data rendemen dengan prosedur perhitungan mengacu pada AOAC (1995).

\section{HASIL DAN PEMBAHASAN}

\section{Minyak Hasil Eksraksi}

Berdasarkan hasil uji pada tiap sampel, diperoleh sejumlah minyak yang menempel pada botol sampel melalui proses penguapan $n$-hexane. Data yang diperoleh menunjukkan bahwa rata-rata berat minyak hasil ekstraksi dari mikroalga jenis Nannochloropsis sp. dengan perlakuan panas yakni 0.018 gram, sedangkan perlakuan sonikator sebesar 0.014 gram, dan kontrol sebesar 0.011 gram. Uji terhadap mikroalga Chlorella sp. menghasilkan minyak lebih besar dari perlakuan sonikator yang mencapai 
0.021 gram, sedangkan perlakuan panas menghasilkan 0.019 gram, dan kontrol sebesar 0.014. Adapun pada mikroalga jenis Spirulina sp., perlakuan sonikator menghasilkan lebih banyak minyak sebesar 0.040 gram sedangkan perlakuan panas menghasilkan 0.024 gram dan kontrol sebesar 0.013 gram. Perbandingan besaran minyak hasil ekstaksi dari ketiga perlakuan pada tiap sampel mikroalga (Tabel 1).

\section{Pengaruh Pemecahan Dinding Sel terhadap Minyak yang Dihasilkan}

Hasil rata-rata berat minyak yang diperoleh menunjukkan bahwa pemecahan dinding sel memberikan hasil yang berbeda pada setiap perlakuan. Berat minyak yang diperoleh menunjukan bahwa teknik pemecahan dinding sel pada mikroalga Spirulina sp. dengan menggunakan sonikator memberikan hasil tertinggi (Tabel 1).

Hasil penelitian Mirshekari $d k k$ (2014) pada sel Chlorella vulgaris juga menyimpulkan bahwa sonikator paling efisien dalam pemecahan dinding sel. Namun Hasil yang agak berbeda diperoleh oleh Lee $d k k$, (2010) yang melaporkan bahwa metode pemecahan dinding sel menggunakan oven microwave (panas) memberikan hasil yang paling tinggi untuk mikroalga jenis Botryococcus sp. Hal ini dapat disebabkan karena struktur dinding sel mikroalga memiliki karakteristik yang unik berdasarkan fase pertumbuhan masing-masing spesies mikroalga, sehingga menghasilkan perbedaan dalam hal ketebalan, kekerasan, dan kandunganya (Safi, dkk. 2015). Kemungkinan lain juga adalah waktu perendaman yang tidak mencukupi untuk $n$-hexane menembus sumber minyak dalam sel. Darwis (2000) dan Susiloningsih (1999) menyatakan' bahwa proses maserasi ekstraksi yang lama akan menghasilkan rendemen minyak yang semakin tinggi. Waktu yang paling baik untuk maserasi ekstraksi yaitu selama 3600 menit (60 jam) (Mokkila, 2004).

\section{Rendemen Minyak Hasil Ekstraksi}

Analisis perhitungan rendemen dilakukan untuk mencari rendemen minyak yang terbesar di antara perlakuan panas, sonikator, dan kontrol pada tiap mikroalga yang diuji. Hasil analisis rendemen dari tiap mikroalga dengan perlakuan yang berbeda ditunjukkan dalam (Tabel 2 dan Gambar 1).

Perhitungan rendemen dari minyak yang berhasil diekstrak menunjukkan nilai rendemen minyak dari mikroalga jenis Spirulina sp. dengan perlakuan sonikator merupakan yang tertinggi yakni $2.01 \%$, sedang perlakuan panas $1.21 \%$ dan kontrol $0.66 \%$. Sedangkan kedua mikroalga lainnya yaitu Chorella sp. memiliki nilai rata-rata $1.08 \%$ dengan perlakuan sonikator, $0.95 \%$ perlakuan panas dan $0.73 \%$ pada kontrol dan Nannochloropsis sp. memiliki nilai ratarata tertinggi $0.71 \%$, perlakuan panas $0.58 \%$ dan kontrol $0.57 \%$.

Hasil rendemen minyak dalam penelitian ini menunjukkan bahwa Spirullina sp. memiliki hasil tertinggi, hal ini dikarenakan dinding selnya terdiri atas glukosamin dan asam muramik yang berasosiasi dengan peptida. Walaupun sulit untuk dicerna, dinding sel Spirulina sp. rapuh sehingga kandungan di dalam sel mudah diakses oleh enzim pencernaan atau pelarut sedangkan Chlorella sp. memberikan hasil yang lebih kecil karena dinding selnya tersusun atas selulosa yang lebih sulit untuk dipecah (Falquet dan Hurni, 2006). Selain itu pengaruh perlakuan dan ukuran mikroalga mempengaruhi rendemen minyak yang dihasilkan (Amini, dkk. 2014).

\section{Hidrokarbon dalam Sel Alga}

Pada penelitian ini digunakan alat sonikator dan teknik pemanasan untuk menghancurkan dinding sel. Kedua teknik ini berhasil memecahkan dinding sel dari masing-masing sampel. Hal ini ditunjukkan dengan tampaknya 
Tabel 1. Berat minyak hasil ekstrak dari tiap sampel uji

\begin{tabular}{|c|c|c|c|c|c|c|}
\hline Sampel & Perlakuan & Ulangan & $\begin{array}{l}\text { Berat Botol } \\
\text { Kaca Terang } \\
(\mathrm{gr})\end{array}$ & $\begin{array}{l}\text { Berat Setelah } \\
\text { Diuapkan } \\
\text { (gr) }\end{array}$ & $\begin{array}{c}\text { Berat Minyak (BB - BB } \\
\text { Setelah Diupkan) } \\
\text { (gr) }\end{array}$ & $\begin{array}{c}\text { Rata-rata Berat } \\
\text { Minyak } \\
(\mathrm{gr})\end{array}$ \\
\hline \multirow[b]{3}{*}{ Nannochloropsis sp. } & \multirow{3}{*}{ Panas } & 1 & 17.881 & 17.897 & 0.015 & \multirow{3}{*}{0.018} \\
\hline & & 2 & 17.768 & 17.789 & 0.020 & \\
\hline & & 3 & 17.996 & 18.013 & 0.017 & \\
\hline \multirow[b]{3}{*}{ Nannochloropsis sp. } & \multirow{3}{*}{ Sonikator } & 1 & 18.320 & 18.337 & 0.016 & \multirow[t]{3}{*}{0.014} \\
\hline & & 2 & 18.175 & 18.189 & 0.013 & \\
\hline & & 3 & 18.389 & 18.401 & 0.012 & \\
\hline \multirow[b]{3}{*}{ Nannochloropsis sp. } & \multirow{3}{*}{ Kontrol } & 1 & 17.864 & 17.876 & 0.012 & \multirow[t]{3}{*}{0.011} \\
\hline & & 2 & 18.033 & 18.046 & 0.012 & \\
\hline & & 3 & 15.829 & 15.840 & 0.010 & \\
\hline \multirow[b]{3}{*}{ Chlorella sp. } & \multirow{3}{*}{ Panas } & 1 & 18.154 & 18.172 & 0.018 & \multirow[t]{3}{*}{0.019} \\
\hline & & 2 & 18.140 & 18.165 & 0.024 & \\
\hline & & 3 & 18.211 & 18.226 & 0.014 & \\
\hline \multirow[b]{3}{*}{ Chlorella sp. } & \multirow{3}{*}{ Sonikator } & 1 & 17.800 & 17.822 & 0.022 & \multirow[t]{3}{*}{0.021} \\
\hline & & 2 & 17.859 & 17.881 & 0.022 & \\
\hline & & 3 & 17.927 & 17.947 & 0.020 & \\
\hline \multirow[b]{3}{*}{ Chlorella sp. } & \multirow{3}{*}{ Kontrol } & 1 & 18.012 & 18.032 & 0.019 & \multirow[t]{3}{*}{0.014} \\
\hline & & 2 & 17.743 & 17.754 & 0.011 & \\
\hline & & 3 & 17.983 & 17.997 & 0.013 & \\
\hline \multirow[b]{3}{*}{ Spirulina sp. } & \multirow{3}{*}{ Panas } & 1 & 16.112 & 16.136 & 0.024 & \multirow[t]{3}{*}{0.024} \\
\hline & & 2 & 18.045 & 18.069 & 0.023 & \\
\hline & & 3 & 16.207 & 16.231 & 0.024 & \\
\hline \multirow[b]{3}{*}{ Spirulina sp. } & \multirow{3}{*}{ Sonikator } & 1 & 18.294 & 18.338 & 0.043 & \multirow[t]{3}{*}{0.040} \\
\hline & & 2 & 18.161 & 18.207 & 0.045 & \\
\hline & & 3 & 17.808 & 17.839 & 0.030 & \\
\hline \multirow[b]{3}{*}{ Spirulina sp. } & \multirow{3}{*}{ Kontrol } & 1 & 17.805 & 17.822 & 0.016 & \multirow[t]{3}{*}{0.013} \\
\hline & & 2 & 16.100 & 16.110 & 0.010 & \\
\hline & & 3 & 18.143 & 18.155 & 0.012 & \\
\hline
\end{tabular}

Keterangan: Nannochloropsis sp. diperoleh dari Balai Besar Budaya Laut Lampung, sedang jenis Chlorella sp., dan Spirulina sp., didapat dari Balai Besar Budidaya Laut dan Payau Jepara. 
Tabel 2. Berat minyak hasil ekstrak dari tiap sampel uji

\begin{tabular}{|l|c|c|c|}
\hline \multirow{2}{*}{\multicolumn{1}{|c|}{ Sampel }} & \multicolumn{3}{|c|}{ Rendemen } \\
\cline { 2 - 4 } & Panas & Sonikator & Kontrol \\
\hline Nannochloropsis sp. & $0.58 \%$ & $0.71 \%$ & $0.57 \%$ \\
\hline Chlorella sp. & $0.95 \%$ & $1.08 \%$ & $0.73 \%$ \\
\hline Spirulina sp. & $1.21 \%$ & $2.01 \%$ & $0.66 \%$ \\
\hline
\end{tabular}

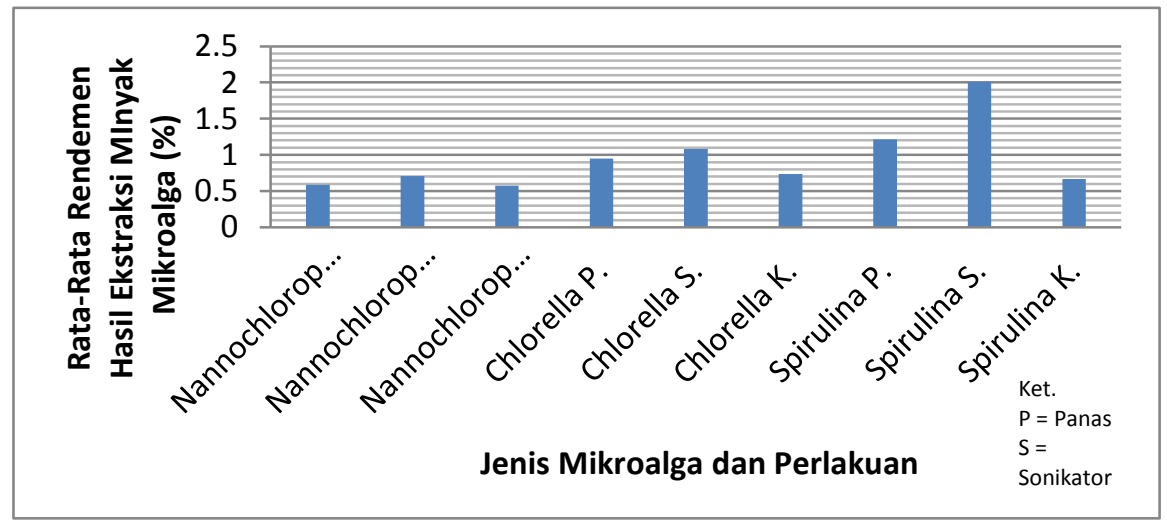

Gambar 1. Rata-Rata Rendemen Minyak

warna kehijauan pada dinding botol sampel (Gambar 2) yang menunjukkan adanya sel kloro plas dari mikroalga yang hancur

Rompas dkk (2016) menyatakan, pada kloroplas terdapat membran luar yang menyelimuti 'stroma homogen'. Dalam stroma ini tertanam sejumlah grana, masingmasing terdiri dari gelembung bermembran, pipih dan discoid (seperti cakram). Membran tilakoid menyimpan pigmen-pigmen fotosintesis dan sistem transport elektron yang terlibat dalam fase fotosintesis yang bergantung pada intensitas cahaya. Dengan demikian senyawa hidrokarbon yang diekstrak dari mikroalga dibutuhkan tahapan proses pemurnian agar minyak atau hidrokarbon alan berwarna bening.
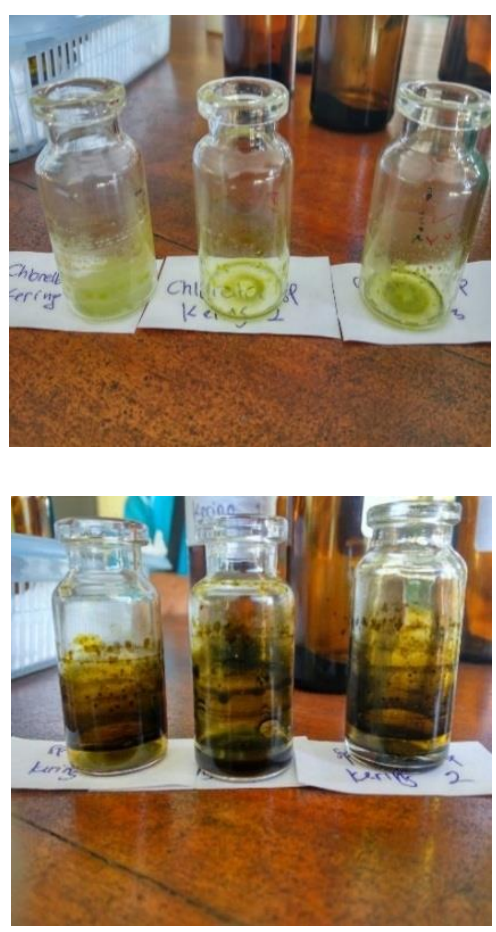

Gambar 2. Bercak Minyak Hasil Ekstraksi Chlorella sp. dan Spirulina sp. 


\section{KESIMPULAN}

Hasil riset menunjukan bahwa teknik pemecahan dinding sel yang terbaik adalah dengan menggunakan sonikator. Mikroalga jenis Spirulina sp. merupakan yang terbanyak memiliki kandungan minyak.

\section{DAFTAR PUSTAKA}

Amini, S., Fitriani, D., Sugiyono., 2014. Pengaruh Perlakuan Pemecahan Dinding Sel Botryococcus braunii dan Nannochloropsis menggunakan Microwave dan Sonikator Terhadap Minyak yang Dihasilkan. JPB Perikanan Vol. 9(1): 41-49.

[AOAC] Association of Official Analytical Chemist. 1995. Official Methods of Analysis. The Association of Official Analytical Chemist. Inc. Washington DC.eh

Darwis, D., 2000. Teknik dasar Laboratorium dalam Penelitian Senyawa Bahan Alam Hayati. Workshop Pengembangan Sumber Daya Manusia dalam Bidang Kimia Organik Bahan Alam Hayati. FMIPA Universitas Andalas Padang. 30 hal.

Doyle A. M.,Bell J. A. 2011. Alga Biofuel: Where We've been, Where We're Going. Nova Science Pup. Inc. 199 hal.

Falquet, J., Hurni, J. P., 2006. The Nutritional Aspects of Spirulina Switzerland:

Antenna Technologies. 25 hal.

Lee, J. Y., Yoo, C., Jun S., Ahn, C., Oh, H., 2010. Comparison of Several Methods for Effective Lipid Extraction from Microalgae. Bioresources Technology, p101.
Mirshekari, S. D., Arabian, R., Khalilzadeh, F., Abaspour., 2014. Investigation of different microalgae cell disruption methods. Proceedings of 15th International Congress of Microbiology. Teheran, Iran: Iranian Society of Microbiology.

Mokkila, M. 2004. Kekuasaan Menggabungkan USG dengan enzim dalam pengolahan jus berry, Di: 2nd Int. Conf. Biocatalysis Makanan dan Minuman,Stuttgart, Jerman.

Rompas, R. M., Kawung N. J., Tilaar S. O., 2015. Bahan Bakar Nabati. Diterbitkan oleh Deepublish.

Rompas, R. M., Ginting, E. L., Lintang, R. A. J., Rumampuk, N. D. C., Paransa, D. S. J, Losung, F., 2016. Biokimia Laut. Penerbit Deepublish, Jogyakarta.206 hal.

Safi, C., Frances, C., Ursu, A. V., Laroche C., Pouzet, C., VacaGarcia, C., Pontalier, P. Y. 2015. Understanding the effect of cell dis-ruption methods on the diffusion of Chlorella vulgaris proteins and pigments in the aqueous phase. Algal Research, 8: 61-68.

Susiloningsih, E. K. B., 1999. Kinetika Ekstraksi Minyak Biji Kacang Tanah Utuh dengan Pelarut Heksana. Universitas Gajah Mada, Yogyakarta. 20 hal. 